Section Editor

Mitchell S.V. Elkind, MD, MS

\title{
Teaching NeuroImages: \\ Internal carotid artery dissection presenting as Villaret syndrome
}

\section{Figure 1 Cranial nerve palsies in Villaret syndrome}

Anna Von Essen*

Gemma Cummins, MRCPI

Mark Manford, MD, FRCP

Correspondence to

Dr. Cummins: gac54@cam.ac.uk
Download teaching slides: Neurology.org
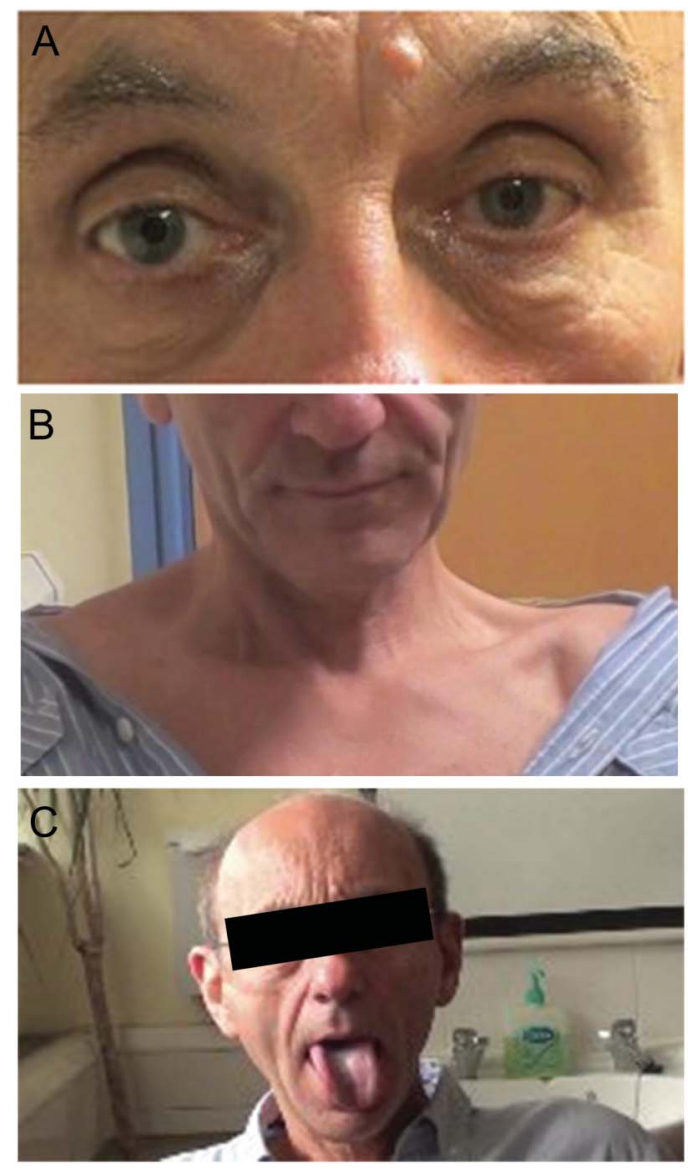

(A) Left Horner sign. (B) Wasting of the left sternocleidomastoid muscle. (C) Deviation of the tongue to the left.

A 63-year-old man presented with headache, hoarseness, and dysphagia. He had a left-sided Horner syndrome and wasting of the left sternocleidomastoid muscle. His tongue was deviated to the left on protrusion (figure 1). MRI and CT angiography revealed a distal left internal carotid artery dissection (figure 2).

Villaret syndrome is a rare clinical entity comprising IX, X, XI, and XII cranial nerve palsies together with Horner sign. ${ }^{1}$ This constellation of signs should prompt the clinician to seek pathology in the retroparotid space,

\begin{tabular}{|ll}
\hline Figure 2 & $\begin{array}{l}\text { Radiologic evaluation of carotid artery } \\
\text { dissection }\end{array}$
\end{tabular}
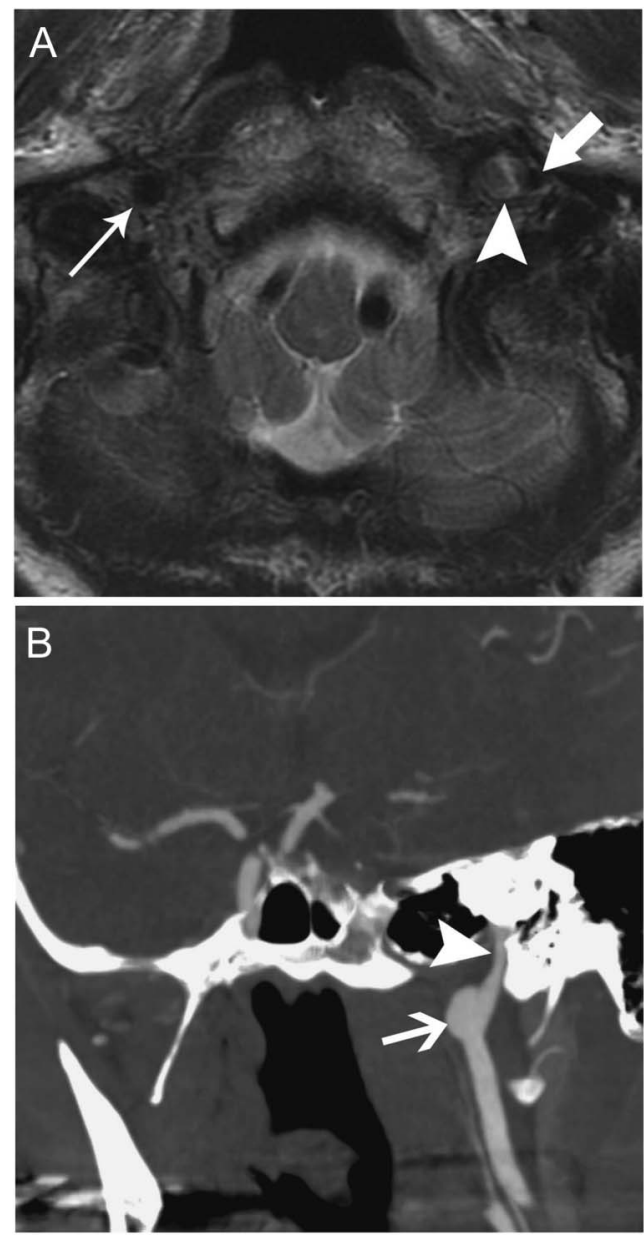

(A) Axial T2-weighted MRI shows normal flow void in the right internal carotid artery (ICA) (thin arrow). The flow void of the left ICA (thick arrow) is narrowed by the medially positioned intramural hematoma, which is of mixed signal intensity (arrowhead). (B) CT angiography shows a pseudoaneurysm of the left ICA (thin arrow) proximal to an area of luminal stenosis (arrowhead).

as this is the only area where the lower 4 cranial nerves and sympathetic fibers to the eye lie in close proximity. When the sympathetic fibers are spared, it is termed Collet-Sicard syndrome. ${ }^{2}$ 


\section{AUTHOR CONTRIBUTIONS}

Oge Okpala: drafting the manuscript, acquisition of data. Anna Von Essen drafting the manuscript, acquisition of data. Dr. Gemma Cummins: drafting and revising the manuscript. Dr. Mark Manford: study design, supervision of study.

\section{ACKNOWLEDGMENT}

The authors thank Dr. Daniel Scoffings, Cambridge University Hospitals, for providing the radiology images.

\section{STUDY FUNDING}

No targeted funding reported.

\section{DISCLOSURE}

The authors report no disclosures relevant to the manuscript. Go to Neurology.org for full disclosures.

\section{REFERENCES}

1. Villaret M. Le syndrome nerveux de l'espace rétro-parotidien postérieur. Rev Neurol 1916;29:188-190.

2. Collet FJ. Sur un nouveau syndrome paralytique pharyngo-larynge par blessure de guerre (hemiplegie glosso-laryngo-scapulo-pharyngee). Lyon Med 1915;124: $121-129$. 


\section{Neurology}

\section{Teaching NeuroImages: Internal carotid artery dissection presenting as Villaret syndrome \\ Ogechukwu Okpala, Anna Von Essen, Gemma Cummins, et al. \\ Neurology 2014;82; $110-\mathrm{e} 111$ \\ DOI 10.1212/WNL.0000000000000266}

\section{This information is current as of March 31, 2014}

\section{Updated Information \& Services \\ Supplementary Material \\ References \\ Subspecialty Collections}

\section{Permissions \& Licensing}

Reprints including high resolution figures, can be found at: http://n.neurology.org/content/82/13/e110.full

Supplementary material can be found at: http://n.neurology.org/content/suppl/2014/03/29/82.13.e110.DC1

This article cites 2 articles, 0 of which you can access for free at: http://n.neurology.org/content/82/13/e110.full\#ref-list-1

This article, along with others on similar topics, appears in the following collection(s):

All Cerebrovascular disease/Stroke

http://n.neurology.org/cgi/collection/all_cerebrovascular_disease_strok e

All Imaging

http://n.neurology.org/cgi/collection/all_imaging

Carotid artery dissection

http://n.neurology.org/cgi/collection/carotid_artery_dissection

Cranial neuropathy

http://n.neurology.org/cgi/collection/cranial_neuropathy

Information about reproducing this article in parts (figures,tables) or in its entirety can be found online at:

http://www.neurology.org/about/about_the_journal\#permissions

Information about ordering reprints can be found online:

http://n.neurology.org/subscribers/advertise

Neurology ${ }^{\circledR}$ is the official journal of the American Academy of Neurology. Published continuously since 1951, it is now a weekly with 48 issues per year. Copyright (O 2014 American Academy of Neurology. All rights reserved. Print ISSN: 0028-3878. Online ISSN: 1526-632X.

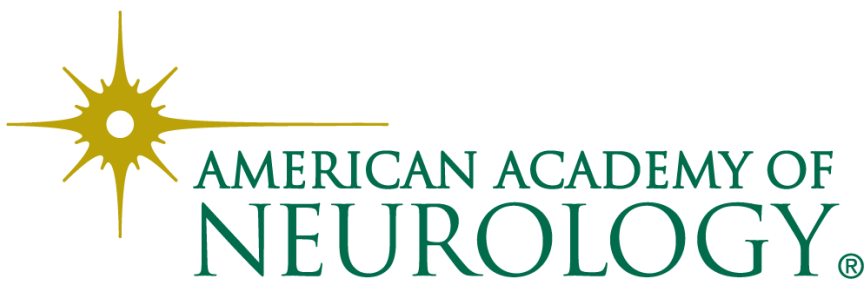

